\title{
Glacier elevation and mass changes over the central Karakoram region estimated from TanDEM-X and SRTM/X-SAR digital elevation models
}

\author{
Melanie RANKL, Matthias BRAUN \\ Institute of Geography, University of Erlangen-Nuremberg, Erlangen, Germany \\ Correspondence: Melanie Rankl <melanie.rankl@fau.de>
}

\begin{abstract}
Snow cover and glaciers in the Karakoram region are important freshwater resources for many down-river communities as they provide water for irrigation and hydropower. A better understanding of current glacier changes is hence an important informational baseline. We present glacier elevation changes in the central Karakoram region using TanDEM-X and SRTM/X-SAR DEM differences between 2000 and 2012. We calculated elevation differences for glaciers with advancing and stable termini or surge-type glaciers separately using an inventory from a previous study. Glaciers with stable and advancing termini since the 1970s showed nearly balanced elevation changes of $-0.09 \pm 0.12 \mathrm{~m} \mathrm{a}^{-1}$ on average or mass budgets of $-0.01 \pm 0.02 \mathrm{Gt} \mathrm{a}^{-1}$ (using a density of $850 \mathrm{~kg} \mathrm{~m}^{-3}$ ). Our findings are in accordance with previous studies indicating stable or only slightly negative glacier mass balances during recent years in the Karakoram. The high-resolution elevation changes revealed distinct patterns of mass relocation at glacier surfaces during active surge cycles. The formation of kinematic waves at quiescent surge-type glaciers could be observed and points towards future active surge behaviour. Our study reveals the potential of the TanDEM-X mission to estimate geodetic glacier mass balances, but also points to still existing uncertainties induced by the geodetic method.
\end{abstract}

KEYWORDS: glacier mass balance, glacier surges, mountain glaciers, remote sensing

\section{INTRODUCTION}

Meltwater from snow and ice originating from High Mountain Asia serves about 800 million people by supplying, for example, drinking water and hydropower (Immerzeel and others, 2010; Kaser and others, 2010). A warming climate accelerates glacier melt, threatening the supply of local communities at a small scale and influencing global sealevel rise at a large scale (e.g. Radić and Hock, 2011; Kääb and others, 2012; Marzeion and others, 2012; Gardner and others, 2013). Most high mountain glaciers in Asia have been affected by mass loss (Bolch and others, 2012). However, in some regions glaciers show anomalous behaviour: glaciers across the Pamir-Karakoram range showed stable or even positive glacier mass balances during recent years (Kääb and others, 2012; Gardelle and others, 2013; Gardner and others, 2013) which have fostered stable or advancing glacier termini (Scherler and others, 2011; Bolch and others, 2012; Rankl and others, 2014). Gardelle and others (2013) found geodetic glacier mass balances of $+1.9 \pm 3.1 \mathrm{Gta}^{-1}$ for the Karakoram $\left(19024 \mathrm{~km}^{2}\right)$ and $+1.3 \pm 1.3 \mathrm{Gta}^{-1}$ for the Pamir $\left(9369 \mathrm{~km}^{2}\right.$ ) between 1999 and 2010 (using a density of $850 \mathrm{~kg} \mathrm{~m}^{-3}$ ). Another study estimated balanced mass budgets between October and November $\left(0.0 \pm 0.8 \mathrm{Gta}^{-1}\right.$ using a zonally variable conversion factor for a glacier area of $21750 \mathrm{~km}^{2}$ ) in the Karakoram using Ice, Cloud and land Elevation Satellite (ICESat) time series between 2003 and 2008 (Kääb and others, 2012). Furthermore, Kääb and others (2015) and Neckel and others (2014) suggested that the glacier mass-balance anomaly extends further east towards the Tibetan Plateau.

The Karakoram is known for a large number of surge-type glaciers (Hewitt, 1998; Copland and others, 2011; Rankl and others, 2014). These glaciers show accelerated surface flow by as much as an order of magnitude and advancing termini during an active surge phase, which lasts a few months to years (Meier and Post, 1969). The active surge phase is accompanied by surface characteristics such as looped and folded medial moraines, crevassed surfaces or ice foliation (Hewitt, 1969; Meier and Post, 1969). Subsequently, flow velocities stagnate and glacier tongues remain stable. The so-called quiescent phase typically endures several years to decades (Meier and Post, 1969). An inventory of surge-type glaciers in the Karakoram was presented by Copland and others (2011) and refined and extended by Rankl and others (2014). The latter contained 1219 glaciers, of which 101 were classified as surge-type glaciers, 969 showed stable termini, 56 were advancing and 93 retreating between 1976 and 2012.

In this study, the bistatic TanDEM-X mission is evaluated in regard to its suitability for calculating glacier elevation changes and geodetic glacier mass balances for parts of the central Karakoram region (Fig. 1). Elevation differences are calculated from interferometrically derived TanDEM-X and SRTM/X-SAR digital elevation models (DEMs). We analyse the elevation differences with respect to glacier type (surgetype, stable, advancing) using the inventory by Rankl and others (2014) and we provide results for different volume-tomass conversion approaches including a consideration of surface and glacier types. Surge-type glaciers are analysed in more detail, differentiating between quiescent or actively surging glaciers in the period 2000-12.

\section{DATA AND METHODS}

The Shuttle Radar Topography Mission (SRTM) acquired interferometric synthetic aperture radar (InSAR) data simultaneously in the C-band and X-band frequencies between 11 and 22 February 2000. Data were acquired between 


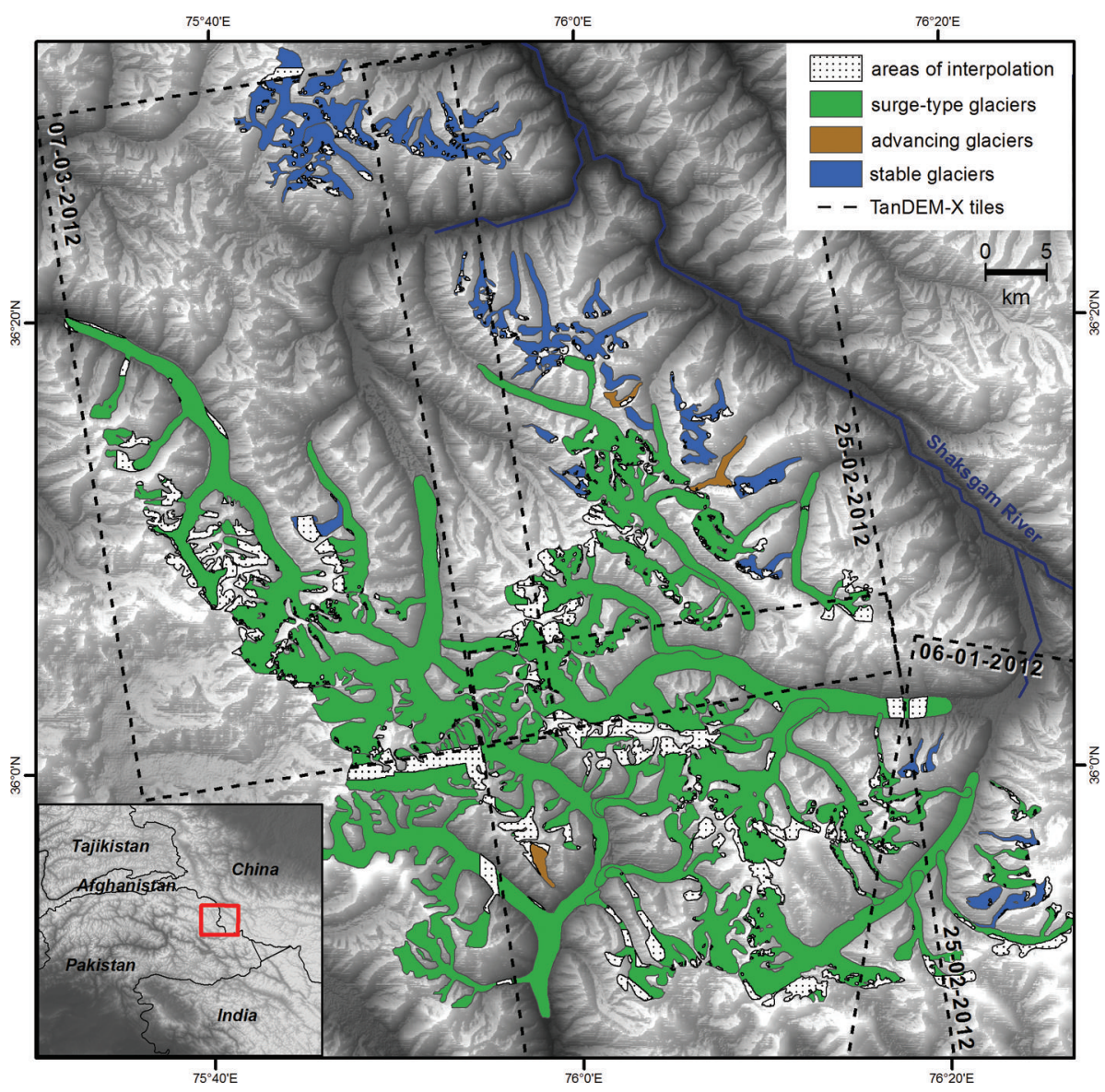

Fig. 1. Overview of glaciers classified as advancing, stable or surge-type (Rankl and others, 2014) and areas of interpolated elevation differences. The extent of each TanDEM-X tile is shown as a dashed box. Background: hillshade of the C-SRTM DEM. The inset map provides the location of the study site in High Asia.

$56^{\circ} \mathrm{S}$ and $60^{\circ} \mathrm{N}$. However, the X-band system operated with a swath width of $\sim 50 \mathrm{~km}$ (C-band $\sim 225 \mathrm{~km})$, which did not allow for global data coverage (Hoffmann and Walter, 2006). The SRTM/X-SAR (X-SRTM) DEM is distributed via the German Aerospace Center with a spatial resolution of 1 arcsec. The SRTM/SIR-C DEM is available in a gap-filled 3 arcsec resolution (http://srtm.csi.cgiar.org) or in a 1 arcsec resolution which still contains data gaps (available at US Geological Survey (USGS)).

The TanDEM-X (TerraSAR-X-Add-on for Digital Elevation Measurements) mission was launched in 2010 by the German Aerospace Center (DLR). TanDEM-X and its twin satellite TerraSAR-X fly in a close helix formation (Krieger and others, 2007). Either the TanDEM-X or TerraSAR-X satellite transmits the radar signal to the ground (the so-called active master). The other satellite then records the backscattered signal (the so-called slave) as does the master satellite (Krieger and others, 2007). The time lag between satellite overpasses during the global DEM mode acquisitions accounts for $3 \mathrm{~s}$ only. Hence, the bistatic acquisitions are very suitable for interferometric processing since temporal and spatial decorrelation are minimized (Krieger and others, 2007; Fritz and others, 2011). We used four TanDEMX/TerraSAR-X StripMap scenes for this study, which were acquired between January and March 2012 (Table 1).

Both missions (X-SRTM and TanDEM-X) operated in the $X$-band frequency $(9.65 \mathrm{GHz})$ and data takes were acquired during winter in the Northern Hemisphere. Due to the high elevation, surface conditions are expected to be similar in 2000 and 2012, with temperatures predominantly below freezing point. Fine-grained, cold winter snow of a few decimetres to metres does not induce a change in the phasescattering centres, i.e. it is transparent for the X-band signal under such cold conditions (Mätzler and Schanda, 1984). Hence, effects of varying, hardly quantifiable penetration depths of the radar signal (Rignot and others, 2001; Gardelle

Table 1. TanDEM-X acquisitions (date (dd-mm-yy) and time) used for interferometric DEM generation. The TanDEM-X tiles of February 2012 were concatenated along the orbit before processing them.

\begin{tabular}{lccc}
\hline Date & Relative orbit & Strip & Direction \\
& & & Height of ambiguity \\
& & & \\
$06-01-12 T 005359$ & 075 & 090 & descending \\
$25-02-12 T 125519 / 25-02-12 T 125526$ & 007 & 080 & ascending \\
$07-03-12 T 125526$ & 007 & 070 & ascending \\
& & & 97
\end{tabular}


and others, 2012) on the geodetic elevation differences are assumed to be small.

Each image pair of the TanDEM-X mission consists of two already co-registered Single-Look Complex files (CoSSC). The TanDEM-X/TerraSAR-X acquisitions were processed by differential interferometry (DInSAR) (Neckel and others, 2013) using Gamma Remote Sensing Software (Werner and others, 2000). After initial interferogram formation and coherence estimation the baseline was determined using the precise satellite orbits delivered with the data. Subsequently, we subtracted the gap-filled SRTM/SIR-C DEM (C-SRTM). This processing step was introduced in order to improve the phase-unwrapping procedure and minimize errors due to, for example, phase jumps in the steep mountainous terrain. The C-SRTM was favoured since it covers the entire Karakoram range, so no additional geometric artefacts are introduced (the X-SRTM is not available gap-filled and with full coverage of the TanDEM$X /$ TerraSAR-X scenes). To generate the differential interferogram the C-SRTM DEM and the TanDEM-X/TerraSAR-X acquisitions were co-registered to each other. For this, an initial look-up table was calculated which was based on the relation between the map coordinates of the C-SRTM DEM segment covering the TanDEM-X/TerraSAR-X master file, and the SAR geometry of the respective master file. Gaps in the look-up table resulting from areas of radar shadows or layover in the TanDEM-X/TerraSAR-X interferogram were filled using linear interpolation between the gap edges in each line of the look-up table (Gamma Remote Sensing, 2007). The co-registration was refined in a subsequent step by calculating the offsets between the master scene and the simulated intensity of the C-SRTM DEM using an intensity cross-correlation algorithm. The corresponding segment of the C-SRTM DEM was then transformed into the SAR geometry of the respective TanDEM-X/TerraSAR-X master scene. The simulated phase of the co-registered C-SRTM DEM and the interferogram of the TanDEM-X/TerraSAR-X bistatic scene were used to generate a differential interferogram. This contains all deviations from the TanDEM-X/ TerraSAR-X interferogram as well as any systematic biases and errors in the C-SRTM DEM. The differential interferogram was filtered using an adaptive filtering approach (Goldstein and Werner, 1998), and areas of low coherence $(<0.3)$ were masked out (Fig. S1 in Supplementary Material at http://igsoc.org/hyperlink/71a024_supp.pdf). Phase unwrapping was then pursued using a minimum-cost flow algorithm. The initial starting point of the unwrapping process was chosen to be on flat, non-glaciated terrain. The unwrapped differential phase was converted to absolute differential heights according to the computed phase-toheight sensitivity. Finally, the differential heights were added back to the C-SRTM DEM in order to achieve the final TanDEM-X elevations for each scene. This last step ensures that the final DEM surface is the one mapped by the X-band phase centres. Assuming that surface conditions were comparable between 2000 and 2012, and that phase centres of the radar return from the same depth, no additional correction for differential radar penetration in 2000 and 2012 was applied. Next, the TanDEM-X DEM tiles were corrected for tropospheric path delays according to Fritz and others (2011).

The resulting TanDEM-X DEM tiles were mosaicked by choosing the February 2012 DEM as a reference. We adjusted the DEM of March 2012 to the reference DEM in regard to the relative height offset by randomly distributing several hundred points over stable, flat and non-glaciated ground in the overlapping areas of the DEMs (Fig. S2 (http:// igsoc.org/hyperlink/71a024_supp.pdf)). The fitting was based on a linear regression analysis using the corresponding points in the overlapping areas. The constant value of the $y$-axis intercept was added to the respective TanDEM$X$ DEM during mosaicking (Fig. S2a (http://igsoc.org/ hyperlink/71a024_supp.pdf)). When mosaicking the scene of January 2012 to the reference DEM, only samples over glaciated areas could be chosen, because no stable, flat and non-glaciated ground was available in the overlapping part. The resulting TanDEM-X DEM mosaic was finally resampled to $30 \mathrm{~m} \times 30 \mathrm{~m}$ pixel spacing.

In order to obtain absolute TanDEM-X DEM heights, we calibrated the TanDEM-X DEM mosaic to the X-SRTM DEM using samples over non-glaciated, low-slope $\left(<15^{\circ}\right)$ ground assuming no elevation differences in these areas between 2000 and 2012. The fitting is again based on the $y$-axis intercept of a linear regression analysis of the samples used.

Finally, we calculated the difference between the XSRTM and the mosaicked TanDEM-X DEMs over glaciers. No further correction of horizontal offsets between the TanDEM-X DEM mosaic and X-SRTM DEM was needed before DEM differencing, since the TanDEM-X DEMs were co-registered to the C-SRTM DEM during interferometric processing (see above) and no systematic horizontal offsets between the C-band and X-band SRTM DEMs are known (Hoffmann and Walter, 2006). Due to the use of two X-band DEMs, errors resulting from different radar penetration are deemed negligible for winter conditions. Since the coverage of the X-SRTM DEM was sparse, we excluded glaciers where $<50 \%$ of the catchment was covered. The X-SRTM DEM is affected by inaccuracies in steep terrain at high altitudes, introduced by shadows and layover effects inherent to the SAR geometry (Ludwig and Schneider, 2006). Thus, we removed elevation differences greater than $\pm 50 \mathrm{~m}$ located above the firn line from the analysis. The threshold of $\pm 50 \mathrm{~m}$ was verified over completely covered glacier catchments, where the elevation differences followed a smooth pattern. Smaller data gaps were iteratively filled by a mean filter with a $5 \times 5$ pixel window. The interpolated areas account for $\sim 19 \%$ of the glaciated area covered by the analysis (Fig. 1 ).

The mean error in the elevation differences was estimated over non-glaciated ground assuming that these areas did not change in height between 2000 and 2012 and that elevations should be equal in both the X-SRTM and TanDEM-X DEMs (Fig. S3 (http://igsoc.org/hyperlink/ 71a024_supp.pdf)). However, Figures S4 and S5 (http:// igsoc.org/hyperlink/71a024_supp.pdf) show large biases in elevation between the two DEMs at altitudes above $5700 \mathrm{~m}$ a.s.l. and in areas steeper than $50^{\circ}$ slope. Additionally, we plotted the distribution of gridcells on-glacier for each $100 \mathrm{~m}$ altitude bin and for each $5^{\circ}$ slope bin (Figs S6 and S7). Over $80 \%$ of the gridcells on-glacier were located below a threshold of $5700 \mathrm{~m}$ a.s.I. (84\%; see also Fig. S6 (http://igsoc.org/hyperlink/71a024_supp.pdf)) and 50 slope (99\%; see also Fig. S7 (http://igsoc.org/hyperlink/ 71a024_supp.pdf)). Thus, the error estimation was restricted to non-glaciated gridcells located below these altitude and slope thresholds following the distribution of gridcells onglacier (Fig. S3 (http://igsoc.org/hyperlink/71a024_supp. pdf)). Additionally, elevation differences off-glacier which exceeded the range of elevation change on-glacier were 
removed from the analysis. Further, we excluded samples used for referencing with the X-SRTM DEM and mosaicking of the TanDEM-X DEM tiles. We used the mean of the elevation differences on those resulting off-glacier areas (25 899 gridcells) as an error measure for our elevation change analysis (Shuman and others, 2011). The samples were distributed over the whole mosaic including potential uncertainties introduced during the various processing steps. Hence, the error accounts for relative height differences which were not eliminated during the mosaicking and fitting processes. The resulting systematic error was $-0.12 \mathrm{~m} \mathrm{a}^{-1}$ on average, the median of the elevation differences off-glacier was $0.06 \mathrm{~m} \mathrm{a}^{-1}$ and the standard deviation $1.90 \mathrm{~m} \mathrm{a}^{-1}$.

For the conversion of the observed glacier volume changes into mass changes a density of ice/firn/snow needs to be assumed. We applied three different density scenarios in order to simplify the comparison to other studies and to show the influence of different conversion approaches on geodetic glacier mass balances. Scenario A uses a fixed density of $900 \mathrm{~kg} \mathrm{~m}^{-3}$ and scenario B uses a density of $850 \mathrm{~kg} \mathrm{~m}^{-3}$ (Gardelle and others, 2013; Huss, 2013) for the entire glacier. Scenario $C$ uses $900 \mathrm{~kg} \mathrm{~m}^{-3}$ for ice below the firn line and $600 \mathrm{~kg} \mathrm{~m}^{-3}$ for snow/firn above the firn line (e.g. Schiefer and others, 2007; Moholdt and others, 2010). The standard error of the detected elevation change was converted into mass assuming the corresponding densities of scenarios $A$ and $B$. For scenario $C$ we chose a mean density of $750 \mathrm{~kg} \mathrm{~m}^{-3}$ in order to convert the error estimate into mass. The altitude of the firn line was determined using multispectral imagery. Based on a Landsat- 8 summer scene (30 July 2013) and the combination of bands 6, 5 and 4, we classified the glaciated areas into snow/firn, ice and debris cover. The transition between snow/firn and ice was assumed to show the firn line. Changes in the firn-line position between 2000 and 2012 were neglected.

The glacier outlines are based on the manually improved glacier inventory of the Karakoram region presented by Rankl and others (2014). Therein, 1219 glaciers were classified as either surge-type, advancing, retreating or stable using Landsat time series between 1976 and 2012 and SAR-based surface velocities. Based on this classification, we separated glacier elevation changes and glacier mass balances for surge-type glaciers and glaciers with advancing or stable termini (Fig. 1). Frontal advances were classified as such when a threshold of 2 pixels $(\sim 60 \mathrm{~m})$ was exceeded during the observation period 1976-2012 (Rankl and others, 2014). The threshold arose from uncertainties during the digitization of glacier outlines using Landsat time series. Glaciers with stable termini did not show frontal changes outside the error bars. The identification of surgetype glaciers was based on several glacier inventories (e.g. Hewitt, 1998; Barrand and Murray, 2006; Copland and others, 2011) which were updated with our own observations based on Landsat time series, surface features and surface velocities (Rankl and others, 2014). Glaciers showing frontal advance, increased surface velocities close to the snout and characteristic surface features were classified as surge-type. Glaciers identified as advancing presented evidence of frontal position changes only, without further evidence to support a surge identification. Within the study area presented here, no retreating glaciers were observed. Glacier centre lines were generated automatically based on the method developed by Kienholz and others (2014).

\section{RESULTS AND DISCUSSION}

\section{Glacier elevation changes}

We calculated glacier elevation changes for 71 glaciers with a total area of $1107.23 \mathrm{~km}^{2}$ (Fig. 2). Out of 71 glaciers, 33 showed surge-type behaviour (area $930.43 \mathrm{~km}^{2}$ ), 35 remained stable (area $166.58 \mathrm{~km}^{2}$ ) and 3 showed advancing termini (area $10.22 \mathrm{~km}^{2}$ ) between 1976 and 2012 according to Rankl and others (2014) (Fig. 1; Table 2). Average elevation changes of glaciers with stable frontal positions were estimated to be $-0.09 \pm 0.12 \mathrm{~m} \mathrm{a}^{-1}$. Glaciers classified as advancing showed, on average, slight thinning within error bars $\left(-0.15 \pm 0.12 \mathrm{~m} \mathrm{a}^{-1}\right)$ as did surge-type glaciers $\left(-0.17 \pm 0.12 \mathrm{~m} \mathrm{a}^{-1}\right)$. Frontal advances of several hundred metres between 1976 and 2012 were found for glaciers with advancing termini (Rankl and others, 2014). Further evidence of surge-type behaviour (e.g. looped and folded moraines, increased surface flow) was not found for advancing glaciers in previous studies using observations not accompanied by elevation change measurements (Hewitt, 1998; Copland and others, 2011; Rankl and others, 2014).

Previous studies including surge-type and non-surge-type glaciers reported both positive and negative elevation changes in the Karakoram region: Kääb and others (2012) showed negative elevation difference trends of $-0.07 \pm$ $0.04 \mathrm{~m} \mathrm{a}^{-1}$ on average using time series from ICESat autumn campaigns between 2003 and 2008. Gardner and others (2013) observed comparable mean changes of $-0.12 \pm$ $0.15 \mathrm{~m} \mathrm{a}^{-1}$ (2003-09) derived from Gravity Recovery and Climate Experiment (GRACE) satellite gravimetry and ICESat altimetry measurements (including the Hindu Kush mountains). However, Gardelle and others (2013) presented positive elevation differences of $+0.12 \pm 0.19 \mathrm{~m} \mathrm{a}^{-1}$ on average for a longer time period (2000-10) using the geodetic method based on SPOT5 (Satellite Pour l'Observation de la Terre) and C-SRTM DEMs. They had to account for the spatially variable C-band radar penetration in order to compare their DEMs derived from optical imagery. Considering glaciers with stable and advancing termini only, we showed average glacier elevation changes of $-0.09 \pm 0.12 \mathrm{~m} \mathrm{a}^{-1}$ for the $2000-$ 12 period. We covered a smaller glaciated area than previous studies, but for a 12 year period. Our high-resolution measurements comprehensively mapped the glaciated areas with a detailed representation of small-scale features (e.g. kinematic waves at surge-type glaciers (glaciers No. 6, 12 and 15 in Fig. 2); thickening and thinning in ice-receiving and ice-reservoir areas, respectively; and differentiated flow patterns at confluence zones (glacier No. 11; Fig. 2)). There was no need for interpolation except in areas of shadows and layover introduced by the SAR geometry.

Stable and advancing glacier termini and only slight glacier thinning in the central Karakoram represent the socalled Pamir-Karakoram anomaly (Gardelle and others, 2013). This glacier mass-balance anomaly was recently found to extend further northeast to the west Kunlun Shan or Tarim basin, and the centre of the anomaly was suggested to be located on the Tibetan Plateau (Neckel and others, 2014; Kääb and others, 2015). An increase in winter precipitation in the Karakoram and eastern Pamir (Archer and Fowler, 2004; Yao and others, 2012) was related to a strengthening of the westerlies in these regions (Bolch and others, 2012). Annual snow accumulation in the Karakoram is dominated by non-monsoonal winter precipitation (Kapnick and others, 2014). In addition, mid-latitude westerlies considerably 


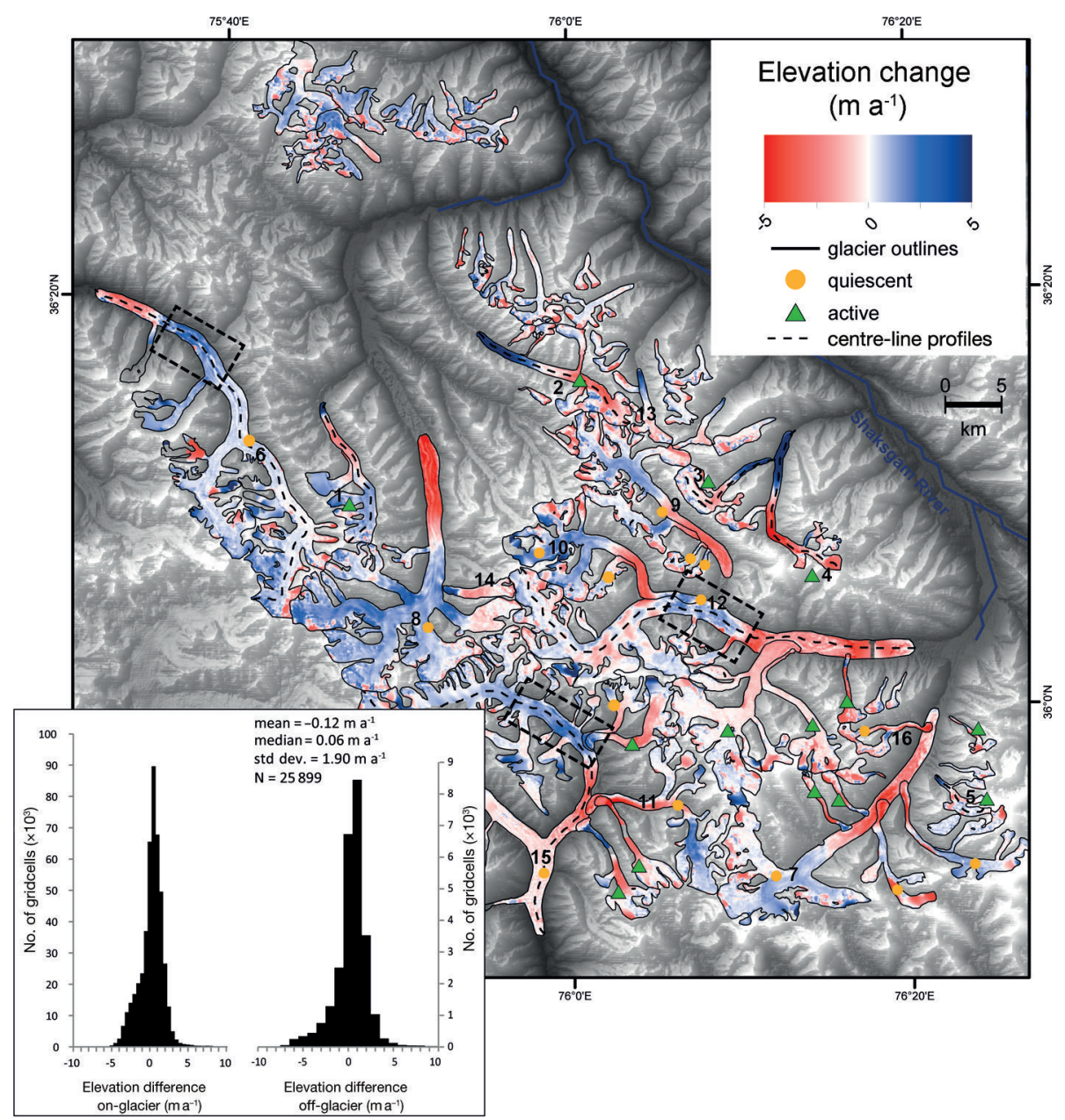

Fig. 2. Elevation differences between 2000 and 2012. Surge-type glaciers in a quiescent phase between 2000 and 2012 are marked with purple circles, active surge-type glaciers with green triangles. Boxes indicate kinematic waves at quiescent surge-type glaciers. Glacier centre-line profiles analysed in Figure 3 are shown. The histograms show the elevation differences on-glacier and off-glacier. The mean, median and standard deviation of the uncertainty estimation are given, as well as the total number of off-glacier samples used. Background: hillshade of the C-SRTM DEM.

influence the mass balance of glaciers over the Tibetan Plateau (Mölg and others, 2014). This confirms the strong influence of westerlies on glacier mass balances in High Asia and even extends their relevance to areas formerly considered to be dominated by monsoonal influence.

\section{Geodetic glacier mass balances}

We computed nearly balanced glacier mass budgets of $-0.01 \pm 0.02 \mathrm{Gta}^{-1}$ (scenarios $\mathrm{A}$ and B) for glaciers with stable and advancing termini or specific mass balances of $-0.08 \pm 0.10$ m w.e. $\mathrm{a}^{-1}$ (Table 2). Scenario C uses a density

Table 2. Average elevation differences and mass balances by glacier type. Elevation changes differed significantly $(p<0.0001)$ according to a Wilcoxon rank-sum test

\begin{tabular}{|c|c|c|c|c|}
\hline & Surge-type (33) & Stable (35) & Advancing (3) & Stable + Advancing (38) \\
\hline $\begin{array}{l}\text { Area (above/below firn line) } \\
\left(\mathrm{km}^{2}\right)\end{array}$ & 930.43 & 166.58 (134.42 / 32.16) & $10.22(5.72 / 4.53)$ & 176.80 \\
\hline $\begin{array}{l}\text { Mean elevation differences } \\
\mathrm{d} h / \mathrm{d} t\left(\mathrm{~m} \mathrm{a}^{-1}\right) \\
\text { above firn line }\left(\mathrm{m} \mathrm{a}^{-1}\right) \\
\text { below firn line }\left(\mathrm{m} \mathrm{a}^{-1}\right)\end{array}$ & $\begin{array}{c}-0.17 \pm 0.12 \\
\text { n.a. } \\
\text { n.a. }\end{array}$ & $\begin{array}{c}-0.09 \pm 0.12 \\
-0.11 \pm 0.12 \\
0.00 \pm 0.12\end{array}$ & $\begin{array}{c}-0.15 \pm 0.12 \\
-0.36 \pm 0.12 \\
0.11 \pm 0.12\end{array}$ & $-0.09 \pm 0.12$ \\
\hline $\begin{array}{l}\text { Mass budget/specific mass b } \\
\text { scenario } A^{*}\left(\mathrm{Gta}^{-1} / \mathrm{m} \text { w.e. } \mathrm{a}^{-1}\right. \\
\text { scenario } \mathrm{B}^{*}\left(\mathrm{Gta}^{-1} / \mathrm{m} \text { w.e. } \mathrm{a}^{-1}\right. \\
\text { scenario } \mathrm{C}^{*}\left(\mathrm{Gta}^{-1} / \mathrm{m} \text { w.e. } \mathrm{a}^{-1}\right.\end{array}$ & $\begin{array}{l}\text { lance } \\
-0.14 \pm 0.10 /-0.16 \pm 0.11 \\
-0.14 \pm 0.09 /-0.15 \pm 0.10 \\
\text { n.a. }\end{array}$ & $\begin{array}{l}-0.01 \pm 0.02 /-0.08 \pm 0.11 \\
-0.01 \pm 0.02 /-0.07 \pm 0.10 \\
-0.01 \pm 0.01 /-0.06 \pm 0.09\end{array}$ & $\begin{array}{c}0.00 \pm 0.001 /-0.13 \pm 0.11 \\
0.00 \pm 0.001 /-0.13 \pm 0.10 \\
0.00 \pm 0.001 / 0.00 \pm 0.09\end{array}$ & $\begin{array}{l}-0.01 \pm 0.02 /-0.08 \pm 0.10 \\
-0.01 \pm 0.02 /-0.08 \pm 0.10 \\
-0.01 \pm 0.01 /-0.09 \pm 0.09\end{array}$ \\
\hline
\end{tabular}

*Density assumptions: scenario A: $900 \mathrm{~kg} \mathrm{~m}^{-3}$; scenario B: $850 \mathrm{~kg} \mathrm{~m}^{-3}$; scenario C: $900 \mathrm{~kg} \mathrm{~m}^{-3}$ below the firn line and $600 \mathrm{~kg} \mathrm{~m}^{-3}$ above the firn line (firn line at $5171.77 \mathrm{~m}$ a.s.l.). The errors given are based on the mean error of elevation differences over non-glaciated ground following the altitude and slope distribution as well as the range of observed elevation changes of glaciated catchments. A mean density of $750 \mathrm{~kg} \mathrm{~m}^{-3}$ is used for the error computation of scenario C. 


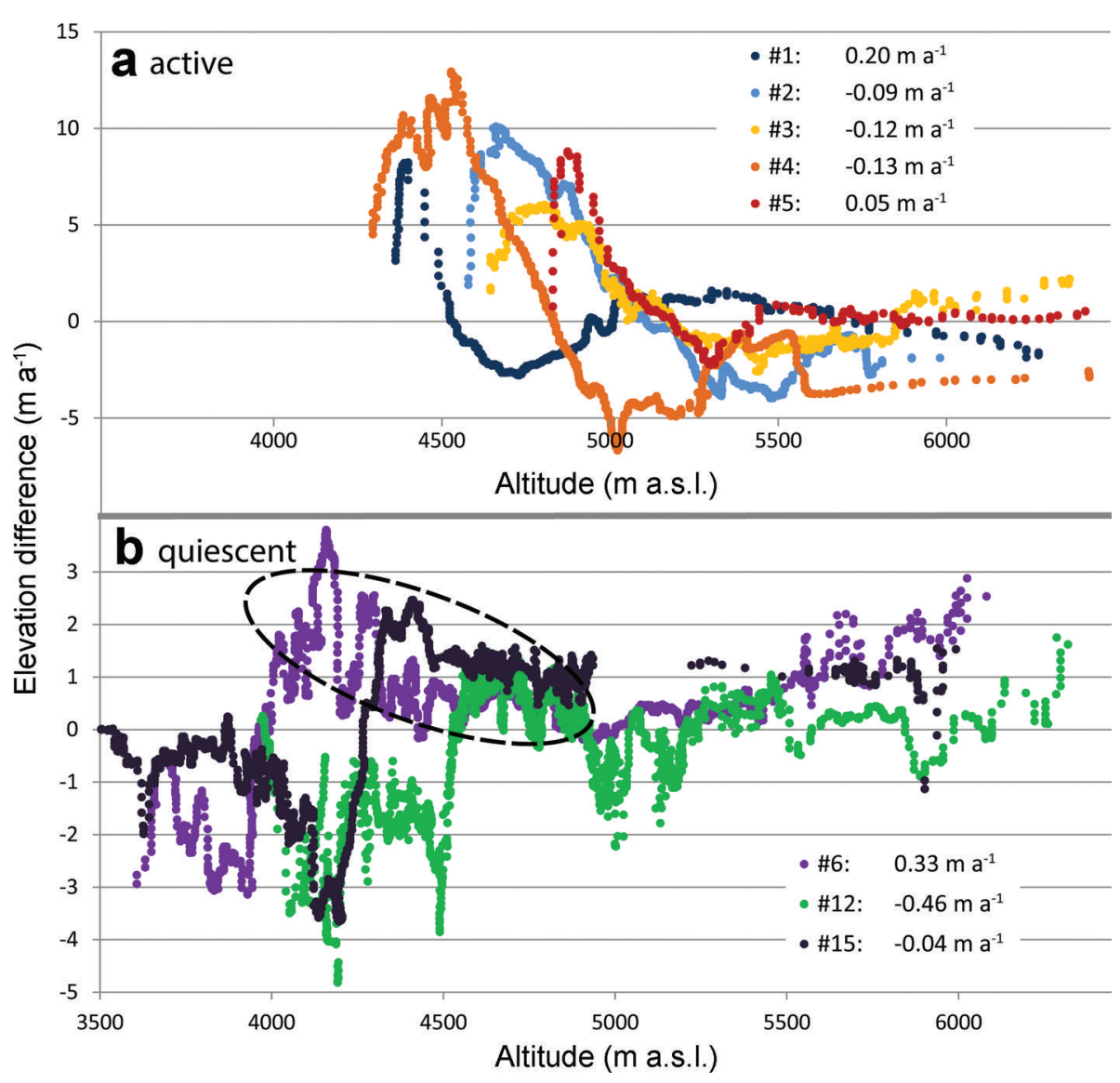

Fig. 3. Averaged glacier elevation differences of (a) five surge-type glaciers in an active surge phase and (b) three glaciers in a quiescent surge cycle between 2000 and 2012. The dashed ellipse marks the formation of a bulge or kinematic wave at quiescent glacier tongues (refer also to dashed boxes in Fig. 2). The error bar of $\pm 0.12 \mathrm{~m} \mathrm{a}^{-1}$ holds for each value given here. The location of the profiles is shown in Figure 2.

of $600 \mathrm{~kg} \mathrm{~m}^{-3}$ for the conversion of volume changes above the firn line and $900 \mathrm{~kg} \mathrm{~m}^{-3}$ for volume changes located below the firn line (e.g. Schiefer and others, 2007; Moholdt and others, 2010). This scenario was applied to glaciers with stable and advancing termini only (Table 2). Due to the relocation of mass during an active surge phase, a zonally variable conversion factor, which changes with altitude, might be inapplicable to these glaciers. We assume that the dynamic relocation, which is also clearly reflected in the elevation differences, is dominated by glacier ice.

The conversion from volume to mass is a crucial factor when assessing glacier mass changes using the geodetic method (Huss, 2013). Different densities need to be applied for snow/firn and ice coverage. Additionally, changes in a glacier's mass balance over time involve changes in the firn density profile. Hence, surface lowering in the accumulation areas expressed using the geodetic method does not necessarily imply a loss of mass, but might be strongly influenced by firn compaction. Due to a lack of in situ measured density profiles, most studies use constant factors when converting ice volume to mass. Huss (2013) found an overestimation of mass changes of $2-15 \%$ when assuming the density of ice for entire glacier catchments. The author recommended applying a density of $850 \pm 60 \mathrm{~kg} \mathrm{~m}^{-3}$ for investigation periods $>5$ years provided that stable glacier mass-balance gradients are present and also that firn area and volume changes are significantly different from zero. In consequence, we suggest scenario $B\left(850 \mathrm{~kg} \mathrm{~m}^{-3}\right)$ and scenario $C$ to be most appropriate to reflect mass changes of non-surge-type glaciers in the Karakoram.

\section{Surge-type glaciers and small-scale surface features}

Glaciers classified as surge-type showed average surface thinning of $-0.17 \pm 0.12 \mathrm{~m} \mathrm{a}^{-1}$ and slightly negative mass budgets within the error bars $\left(-0.14 \pm 0.09 \mathrm{Gta}^{-1}\right.$; scenario B). Elevation-change measurements are a suitable tool for mapping and monitoring surge-type glaciers. The relocation of mass from the ice reservoir to the ice-receiving area during an active surge phase can be quantified. In subsequent years, these ice masses can downwaste faster due to the higher ablation rates in these lower areas. Figure 2 illustrates the relocation of mass: actively surging glaciers (between 2000 and 2012) gained mass close to the snout and lost mass in the ice reservoir area. The most prominent examples are glaciers No. 1 to No. 5 (Fig. 2). For these glaciers, the elevation differences were extracted along their centre lines and plotted against altitude (Fig. 3a). Elevation gain and loss as well as the respective change with altitude become visible in more detail. The combination with other observations based on remote sensing enables the identification of surge-type glaciers in an active surge cycle and the quantification of the relocation of mass without the need for in situ measurements. Glaciers No. 13 and No. 14 (Fig. 2) could not be identified as actively surging glaciers without elevation change measurements or additional multitemporal velocity datasets as in previous studies (e.g. Copland and others, 2011; Rankl and others, 
2014). Yet the relocation of mass from the ice-reservoir area to the ice-receiving area is visible in Figure 2, where a concentrated mass gain close to the glacier snouts is observable. A previous study investigating glacier elevation changes using the geodetic method came to the same conclusion for both glaciers (Gardelle and others, 2013). Thus, we suggest that thinning and thickening at glaciers No. 13 and No. 14 was independent of climatic forcing, since the elevation change was driven by surge-type behaviour. These findings stress the importance of including elevation-change measurements when analysing glaciers in regard to surge-type behaviour.

Quiescent surge-type glaciers thinned considerably along their lower tongues between 2000 and 2012 (e.g. glaciers No. 6 and No. 12 in Figure 2: $\sim 6 \pm 0.12 \mathrm{~m} \mathrm{a}^{-1}$ on average). However thickening is visible between $\sim 4100$ and $\sim 5000$ ma.s.l. (dashed labelling in Fig. 2 on glaciers No. 6, No. 12, No. 15; Fig. 3b). Upstream of these areas, elevation changes were nearly zero or increased slightly towards the glaciers' origins. We think that the elevation gain visible in Figure $3 \mathrm{~b}$ (see dashed ellipse, glaciers No. 6, No. 12, No. 15 in Fig. 2) represents the formation of a bulge (Clarke and others, 1984) or kinematic wave (Mayer and others, 2011). An active surge cycle will be initiated provided that the size of the bulge exceeds a threshold and the thermal regime of the glacier or the meltwater supply changes. In a previous study, SAR-based surface velocities were analysed for Skamri glacier (No. 12 in Fig. 2; Rankl and others, 2014). The glacier was in an active surge phase prior to 1990, sped up in $1992\left(\sim 0.8 \mathrm{~m} \mathrm{~d}^{-1}\right)$ and slowed down again. It remained quiescent until 2009 with surface velocities of $\sim 0.1$ $0.2 \mathrm{~m} \mathrm{~d}^{-1}$. However, surface flow rose again in 2011, reaching velocities of up to $1.5 \mathrm{~m} \mathrm{~d}^{-1}$ (Rankl and other, 2014). The area of increased surface speed coincides with the area of thickening between $\sim 4500$ and $\sim 5000$ ma.s.l. (dashed box at glacier No. 12 in Fig. 2). Hence, there are strong indications that Skamri glacier has entered a new active phase of the surge cycle. The same might be true for Nobande Sobonde glacier (No. 15) or Virjerab glacier (No. 6). Multitemporal information on surface flow (e.g. Quincey and others, 2011) or repeated observations of the TanDEM$X$ mission could confirm this interpretation and even provide a better understanding of the processes involved.

High-resolution elevation differences allow for a detailed analysis of ablation/accumulation patterns at confluence zones. Glacier No. 11 (Chiring glacier; Fig. 2) is fed by three tributaries. The main trunk of Chiring glacier thinned during the observation period after its last active surge phase ended in 1995 (Hewitt, 2007). However, its northernmost tributary showed hardly changed surface elevations and is identifiable as a northern branch even below the point of confluence. Another interesting small-scale feature is visible at the glacier tongue (Fig. 2). The glacier surged between 1995 and 2000 and ran into the heavily debris-covered tongue of Sarpo Laggo glacier. During the advance of its tongue, mass was shifted down-glacier and was subsequently affected by melt. After the surge, the largest part of the advanced glacier tongue was debris-free. In contrast, the surrounding tongue of Sarpo Laggo glacier hardly thinned (Fig. 2), which can be attributed to the thicker debris cover. This demonstrates the utility of high-resolution DEM comparison as small-scale ablation patterns became apparent. Further analysis of such patterns could help to better quantify the degree of protection debris provides against surface melt.

\section{Accuracy assessment}

Elevation differences between the X-SRTM and TanDEM-X DEMs off-glacier were plotted as a function of altitude (Berthier and others, 2006) and slope over non-glaciated ground (Figs S4 and S5 (http://igsoc.org/hyperlink/ 71a024_supp.pdf)). We detected elevation biases both with increasing altitude (>5700 ma.s.I.; Fig. S4 (http://igsoc.org/ hyperlink/71a024_supp.pdf)) and slope (>50; Fig. S5 (http:// igsoc.org/hyperlink/71a024_supp.pdf)). This is in agreement with Ludwig and Schneider (2006), who found an increased mean error of the X-SRTM DEM for slopes larger than $35^{\circ}$. Highest deviations of up to $30 \mathrm{~m}$ were reported for slopes of $50^{\circ}$. Additionally, due to the effect of radar shadows, maximum height errors of $30 \mathrm{~m}$ were found in the X-SRTM DEM on north- and west-facing slopes (Ludwig and Schneider, 2006). In the present study, uncertainties in glacier elevation differences were estimated only for altitudes $\leq 5700 \mathrm{~m}$ a.s.l. and slopes shallower than $50^{\circ}$. Height biases at altitudes $>5700 \mathrm{~m}$ a.s.l. and in very steep terrain were excluded from the error estimation. Additionally, the values used for the uncertainty estimation were restricted to the range of elevation differences measured on-glacier. We hypothesize that inaccuracies in the measured elevation differences on-glacier at high altitudes (>5700 m a.s.l.) were mainly influenced by the X-SRTM DEM, which resulted in an overestimation of thinning in these altitudinal bands. An overestimation of thinning in accumulation areas in our study would further strengthen the evidence for anomalous behaviour of Karakoram glaciers with positive or balanced glacier mass budgets (Kääb and others, 2012; Gardelle and others, 2013). Additional height errors might be induced by the mosaicking of the TanDEM-X DEM tiles. However, the correlation coefficients between the TanDEM-X DEM reference tile (25 February 2012) and the tiles to be calibrated are very high $\left(R^{2}=\sim 1\right.$; Fig. S2 (http://igsoc.org/hyperlink/71a024_ supp.pdf)). In consequence, height differences in the final mosaic in overlapping areas are assumed to be negligible.

Due to the use of the same radar frequency, we did not apply a correction for the spatially and temporally variable penetration depths of the SAR signal from different wavelengths or as necessary when comparing optical with SARderived DEMs. Half of the mountain range is located above 5000 ma.s.l. (Copland and others, 2011). Thus, dry snow conditions can be assumed resulting in no change in the phase-scattering centres of the X-band SAR signal. Yet the occurrence of melt events before image acquisitions cannot be ruled out completely, so the layering of the snowpack might have changed in time. The penetration of the signals' phase centres between image acquisitions would then have been different. However, we do not think that the radar penetration would be affected in the 12 year observation time to a magnitude that would significantly bias the measurements. Accounting for the penetration depths (e.g. when comparing optical data to the C- or X-band SRTM DEMs) implies detailed knowledge of the surface and snowcover conditions that is not available for the region. For C-band, penetration was estimated to range between $9 \pm 2$ and $1 \pm 2 \mathrm{~m}$ for frozen firn and ice in Greenland (Rignot and others, 2001); under dry snow conditions it can be even more. Penetration of the X-band frequency into snow, firn and ice is assumed to be smaller (Ulaby and others, 1986; Gardelle and others, 2012). Groh and others (2014) found a height bias of $\sim 5 \mathrm{~m}$ when comparing interferometric X-band heights and NASA IceBridge laser altimetry over dry snow in 
Antarctica. Seehaus and others (2015) showed a seasonally changing X-band signal phase centre depth in the range 2$3 \mathrm{~m}$. In consequence, elevation change measurements of previous studies using different sources of elevation data (Berthier and others, 2007; Gardelle and others, 2013) are affected by uncertainties resulting from the correction of the radar penetration depth.

\section{CONCLUSIONS}

We have shown glacier elevation differences between 2000 and 2012 for parts of the central Karakoram range using the geodetic method based on TanDEM-X and X-SRTM DEMs. Our measurements are mostly independent of temporal decorrelation between image acquisitions due to the bistatic TanDEM-X imaging mode. We suggest that there is little influence of differential X-band penetration on the elevation change measurements. We applied different approaches in order to convert glacier volume changes to glacier mass changes. Based on the classification in Rankl and others (2014), we showed elevation changes for surge-type, stable and advancing glaciers separately. Surge-type glaciers indicated slight surface lowering within error bars between 2000 and 2012 as did advancing glaciers. The majority of the studied glaciers showed stable termini during the observation period and only slight thinning of $-0.09 \pm$ $0.12 \mathrm{~m} \mathrm{a}^{-1}$ on average, corresponding to a mass change of $-0.01 \pm 0.02 \mathrm{Gta}^{-1}$ (scenario B). Our analysis is in accordance, within error bars, with previous studies investigating glacier elevation and mass changes in the Karakoram (e.g. Kääb and others, 2012; Gardelle and others, 2013) and confirms the anomalous behaviour of glaciers there, termed the Pamir-Karakoram anomaly (Gardelle and others, 2013). The high resolution of both the TanDEM-X and X-SRTM DEMs revealed small-scale features of glacier behaviour (e.g. the relocation of ice from the reservoir to the receiving area during an active surge event, kinematic waves and differences of surface lowering under debris cover and on bare glacier tongues). The combination of SAR-based surface velocities and elevation change measurements seems to bear high potential to better understand the glacier surge processes in the Karakoram.

We have demonstrated the suitability of the bistatic TanDEM-X Mission to study glacier volume changes of larger regions but also consider individual glacier catchments. The advantages against optical DEM differencing with respect to SRTM are that no additional corrections are required in order to account for the differential signal penetration. Sparse point-based measurements derived from, for example, laser altimetry (e.g. ICESat) are complemented by a sound statistical sampling density, even in smaller catchments. Unfortunately, globally comprehensive coverage of the X-SRTM DEM is not available due to the limited swath width.

We want to stress the importance of monitoring surgetype glaciers in the Karakoram and other high mountain areas using repeat remote sensing. Rapidly advancing glacier tongues might dam river valleys and hence threaten local communities. Failure of the moraine-dammed rivers might result in glacial lake outburst floods, which are very common in the Karakoram (Hewitt, 2014). The study demonstrates the potential of satellite missions like TanDEM-X to remap such regions regularly (e.g. annually or twice a year) in order to reveal change and provide early warnings.

\section{ACKNOWLEDGEMENTS}

This study was kindly supported with TanDEM-X data under DLR AO mabra_XTI_GLAC0264. Landsat data were kindly provided by USGS and SRTM/X-SAR data by DLR, while SRTM/SIR-C data were obtained from the Consortium for Spatial Information of the Consultative Group on International Agricultural Research (CGIAR-CSI). The research was financially supported by the University of ErlangenNuremberg, the Helmholtz-Alliance 'Remote Sensing and Earth System Dynamics' and DLR/BMWi grant FKZ 50E1414.

\section{REFERENCES}

Archer D and Fowler H (2004) Spatial and temporal variations in precipitation in the Upper Indus Basin: global teleconnections and hydrological implications. Hydrol. Earth Syst. Sci. 8(1), 47-61 (doi: 10.5194/hess-8-47-2004)

Barrand NE and Murray T (2006) Multivariate controls on the incidence of glacier surging in the Karakoram Himalaya. Arct. Antarct. Alp. Res., 38(4), 489-498 (doi: 10.1657/1523-0430 (2006)38[489:MCOTIO]2.0.CO;2)

Berthier E, Arnaud Y, Vincent C and Rémy F (2006) Biases of SRTM in high-mountain areas: implications for the monitoring of glacier volume changes. Geophys. Res. Lett., 33(8) (doi: 10.1029/2006GL025862)

Berthier E, Arnaud Y, Kumar R, Ahmad S, Wagnon P and Chevallier $P$ (2007) Remote sensing estimates of glacier mass balances in the Himachal Pradesh (Western Himalaya, India). Remote Sens. Environ., 108(3), 327-338 (doi: 10.1016/j.rse.2006.11.017)

Bolch T and 11 others (2012) The state and fate of Himalayan glaciers. Science 336(6079), 310-314 (doi: 10.1126/science. 1215828)

Clarke GK, Collins S and Thompson D (1984) Flow, thermal structure, and subglacial conditions of a surge-type glacier. Can. J. Earth Sci., 21(2), 232-240 (doi: 10.1139/e84-024)

Copland L and 7 others (2011) Expanded and recently increased glacier surging in the Karakoram. Arct. Antarct. Alp. Res. 43(4), 503-516 (doi: 10.1657/1938-4246-43.4.503)

Fritz T, Rossi C, Yague-Martinez N, Rodriguez-Gonzalez F, Lachaise $M$ and Breit $H$ (2011) Interferometric processing of TanDEM-X data. In IGARSS 2011, International Geoscience and Remote Sensing Symposium, 24-29 July 2011, Vancouver, B.C., Canada. Proceedings. Institute of Electrical and Electronics Engineers, Piscataway, NJ, 2428-2431 (doi: 10.1109/ IGARSS.2011.6049701)

Gamma Remote Sensing (2007) GAMMA Differential Interferometry and Geocoding Software (DIFF/GEO). Gamma Remote Sensing, Gumligen

Gardelle J, Berthier E and Arnaud Y (2012) Impact of resolution and radar penetration on glacier elevation changes computed from DEM differencing. J. Glaciol., 58(208), 419-422 (doi: 10.3189/ 2012JoG11J175)

Gardelle J, Berthier E, Arnaud Y and Kääb A (2013) Region-wide glacier mass balances over the Pamir-Karakoram-Himalaya during 1999-2011. Cryosphere, 7(4), 1263-1286 (doi: 10.5194/ tc-7-1263-2013)

Gardner AS and 9 others (2013) A reconciled estimate of glacier contributions to sea level rise: 2003 to 2009. Science, 340(6134), 852-857 (doi: 10.1126/science.1234532)

Goldstein RM and Werner CL (1998) Radar interferogram filtering for geophysical applications. Geophys. Res. Lett., 25(21), 40354038 (doi: 10.1029/1998GL900033)

Groh A and 11 others (2014) Mass, volume and velocity of the Antarctic ice sheet: present-day changes and error effects. Surv. Geophys., 35(6), 1481-1505 (doi: 10.1007/s10712-014-9286-y)

Hewitt K (1969) Glacier surges in the Karakoram Himalaya (central Asia). Can. J. Earth Sci. 6(4), 1009-1018 (doi: 10.1139/e69-106) 
Hewitt K (1998) Recent glacier surges in the Karakoram Himalaya, South Central Asia. Eos, 79(8), 104-105

Hewitt K (2007) Tributary glacier surges: an exceptional concentration at Panmah Glacier, Karakoram Himalaya. J. Glaciol. 53(181), 181-188 (doi: 10.3189/172756507782202829)

Hewitt K (2014) Glaciers of the Karakoram Himalaya: glacial environments, processes, hazards and resources. Springer, Berlin

Hoffmann J and Walter D (2006) How complementary are SRTM-X and-C band digital elevation models? Photogramm. Eng. Remote Sens., 72(3), 261-268 (doi: 10.14358/PERS.72.3.261)

Huss M (2013) Density assumptions for converting geodetic glacier volume change to mass change. Cryosphere 7(3), 877-887 (doi: 10.5194/tc-7-877-2013)

Immerzeel WW, Van Beek LP and Bierkens MF (2010) Climate change will affect the Asian water towers. Science, 328(5984), 1382-1385 (doi: 10.1126/science.1183188)

Kääb A, Berthier E, Nuth C, Gardelle J and Arnaud Y (2012) Contrasting patterns of early twenty-first-century glacier mass change in the Himalayas. Nature 488(7412), 495-498 (doi: 10.1038/nature11324)

Kääb A, Treichler D, Nuth C and Berthier E (2015) Brief Communication: Contending estimates of 2003-2008 glacier mass balance over the Pamir-Karakoram-Himalaya. Cryosphere, 9(2), 557-564 (doi: 10.5194/tc-9-557-2015)

Kapnick SB, Delworth TL, Ashfaq M, Malyshev S and Milly PCD (2014) Snowfall less sensitive to warming in Karakoram than in Himalayas due to a unique seasonal cycle. Nature Geosci., 7(11), 834-840 (doi: 10.1038/ngeo2269)

Kaser G, Großhauser M and Marzeion B (2010) Contribution potential of glaciers to water availability in different climate regimes. Proc. Natl Acad. Sci., 107(47), 20 223-20227 (doi: 10.1073/pnas.1008162107)

Kienholz C, Rich JL, Arendt AA and Hock R (2014) A new method for deriving glacier centerlines applied to glaciers in Alaska and northwest Canada. Cryosphere 8(2), 503-519 (doi: 10.5194/tc8-503-2014)

Krieger G and 6 others (2007) TanDEM-X: a satellite formation for high-resolution SAR interferometry. IEEE Trans. Geosci. Remote Sens., 45(11), 3317-3341 (doi: 10.1109/TGRS.2007.900693)

Ludwig R and Schneider P (2006) Validation of digital elevation models from SRTM X-SAR for applications in hydrologic modeling. ISPRS J. Photogramm. Remote Sens., 60(5), 339-358 (doi: 10.1016/j.isprsjprs.2006.05.003)

Marzeion B, Jarosch AH and Hofer M (2012) Past and future sealevel change from the surface mass balance of glaciers. Cryosphere 6(6), 1295-1322 (doi: 10.5194/tc-6-1295-2012)

Mätzler C and Schanda E (1984) Snow mapping with active microwave sensors. Remote Sens., 5(2), 409-422 (doi: 10.1080/ 01431168408948816)

Mayer C, Fowler A, Lambrecht A and Scharrer K (2011) A surge of North Gasherbrum Glacier, Karakoram, China. J. Glaciol., 57(205), 904-916 (doi: 10.3189/002214311798043834)

Meier MF and Post A (1969) What are glacier surges? Can. J. Earth Sci., 6(4), 807-817 (doi: 10.1139/e69-081)
Moholdt G, Nuth C, Hagen JO and Kohler J (2010) Recent elevation changes of Svalbard glaciers derived from ICESat laser altimetry. Remote Sens. Environ., 114(11), 2756-2767 (doi: 10.1016/j.rse. 2010.06.008)

Mölg T, Maussion F and Scherer D (2014) Mid-latitude westerlies as a driver of glacier variability in monsoonal High Asia. Nature Climate Change, 4(1), 68-73 (doi: 10.1038/nclimate2055)

Neckel N, Braun A, Kropáček J and Hochschild V (2013) Recent mass balance of the Purogangri Ice Cap, central Tibetan Plateau, by means of differential X-band SAR interferometry. Cryosphere, 7(5), 1623-1633 (doi: 10.5194/tc-7-1623-2013)

Neckel N, Kropáček J, Bolch T and Hochschild V (2014) Glacier mass changes on the Tibetan Plateau 2003-2009 derived from ICESat laser altimetry measurements. Environ. Res. Lett., 9(1), 014009 (doi: 10.1088/1748-9326/9/1/014009)

Quincey DJ, Braun M, Glasser NF, Bishop MP, Hewitt $K$ and Luckman A (2011) Karakoram glacier surge dynamics. Geophys Res. Lett., 38, L18504 (doi: 10.1029/2011GL049004)

Radić V and Hock R (2011) Regionally differentiated contribution of mountain glaciers and ice caps to future sea-level rise. Nature Geosci., 4(2), 91-94 (doi: 10.1038/ngeo1052)

Rankl M, Kienholz C and Braun M (2014) Glacier changes in the Karakoram region mapped by multimission satellite imagery. Cryosphere 8(3), 977-989 (doi: 10.5194/tc-8-977-2014)

Rignot E, Echelmeyer K and Krabill W (2001) Penetration depth of interferometric synthetic-aperture radar signals in snow and ice. Geophys. Res. Lett., 28(18), 3501-3504 (doi: 10.1029/ 2000GL012484)

Scherler D, Bookhagen B and Strecker M. (2011) Spatially variable response of Himalayan glaciers to climate change affected by debris cover. Nature Geosci., 4(3), 156-159 (doi: 10.1038/ ngeo1068)

Schiefer E, Menounos B and Wheate R (2007) Recent volume loss of British Columbian glaciers, Canada. Geophys. Res. Lett., 34(16), L16503 (doi: 10.1029/2007GL030780)

Seehaus T, Marinsek S, Helm V, Skvarca P and Braun M (2015) Changes in ice dynamics, elevation and mass discharge of Dinsmoor-Bombardier-Edgeworth glacier system, Antarctic Peninsula. Earth Planet. Sci. Lett., 427, 125-135 (doi: 10.1016/j.epsl.2015.06.047)

Shuman CA, Berthier E and Scambos TA (2011) 2001-2009 elevation and mass losses in the Larsen $A$ and $B$ embayments, Antarctic Peninsula. J. Glaciol., 57(204), 737-754 (doi: 10.3189/ $002214311797409811)$

Ulaby FT, Moore RK and Fung AK (1986) Microwave remote sensing, active and passive. Vol. III: From theory to applications. Artech House, Norwood, MA

Werner C, Wegmüller U, Strozzi T and Wiesmann A (2000) Gamma SAR and interferometric processing software. Proceedings of the ERS-ENVISAT Symposium, Gothenburg, Sweden, 16-20 October 2000. European Space Agency, Noordwijk

Yao T and 9 others (2012) Different glacier status with atmospheric circulations in Tibetan Plateau and surroundings. Nature Climate Change, 2(9), 663-667 (doi: 10.1038/nclimate1580) 